and seismology. It would be the first of its kind in Europe.

Dr A. Zátopek from Czechoslovakia, an expert in seismology, assembled and analysed macro- and microseismic data with the conclusion that the epicentral intensity was IX MCS and the focal depth $5 \mathrm{~km}$ at Skopje, the epicentre. In all, the shaken area covered $105 \mathrm{~km}^{2}$. The earthquake was described in general terms as a superficial or shallow tectonic, composed of several shocks, with typical small block structure mechanism within the epicentral area. Dr Zátopek recommended that there should be detailed studies of the seismology of Yugoslavia.

The final part of the report was produced by Dr A. A. Sorsky of the University of Moscow, who studied the geological and tectonic factors of the 1963 earthquake. His conclusions include the fact that Skopje is on a seismologically dangerous area, and earthquakes are liable to occur there again. Seismological and geological data are being collected by Yugoslav scientists so that a microregionalization map can be compiled, from which can be worked out the areas of most movement and consequently most seismological danger. Provided building sites are chosen according to this map, Dr Sorsky believes that building should continue on the present site of the city.

\section{Keeping Physicists Aware}

CoMPARATIVELY recently there has emerged a new type of indexing journal, aimed at alerting readers quickly to titles of papers written in their respective fields. In their simplest form, current awarencss journals, as they are called, consist of a collection of facsimile reproductions of contents tables of individual journals. The weekly list, Current Contents, published by the Institute for Scientific Information, Philadelphia, since 1958 , is a well known example of a journal of this type. The Polish Academy of Sciences produces a similar key to the Polish literature. A more sophisticated example of a current title index is provided by the scmi-monthly Chemical Titles, a product of the Chemical Abstracts service, which is a computer produced keyword index.

In January 1966, the Institution of Electrical Engineers (IEE), in association with the American Institute of Physics (AIP), inaugurated a new current awareness journal called Current Papers in Physics to be used in conjunction with Physics Abstracts produced by the same institutions. The IEE also publishes two other current awareness journals, Current Papers on Control and Current Papers in Electrotechnology; and two other abstract journals, Control Abstracts and Electrical and Electronics Abstractstogether the journals are known as INSPEC (Information Service in Physics, Electrotechnology and Control).

It was decided, before Current Papers in Physics $(C P P)$ began publication, that it would be sensible to assess the need for this new journal and its usefulness. During its first year of publication (1966) a joint study was therefore undertaken in Britain by the Aslib Research Department for the IEE and in the United States by the then Documentation Research Project staff of AIP. The first report of this study has recently been published (Results of Questionnaire on Current Awareness Methods used by Physicists prior to Publication of "Current Papers in Physics").
Panels of physicists were set up in Britain (268 physicists) and the United States (682 physicists). Before $C P P$ appeared, the panel members received the first of a series of three tests. This initial questionnaire covered panel composition; methods used by physicists to keep up to date before $C P P$; and expectations of a current awareness journal in the field of physics. Results of this questionnaire are given in this report. Two later questionnaires covered physicists' comments on CPP and suggested improvements, and a record of the actual use made of the publication and the order in which sections were scanned. Reports of these studies are to be published later.

The results of the first survey show that current awareness journals were not much used by panel members before CPI' appeared. In general, the use tended to follow the pattern of the country of publication. The journals published in the UK--British Technology Index and Current Papers for the Professional Electrical and Electronics Engineer (now Current Papers in Electrotechnology) were more uscd in the UK than in the US, and the reverse was true for the US physicists in terms of Chemical Titles, Current Contents: Physical Sciences, for example. Physicists co-operating in the study seemed to rely mainly on scanning current issues of journals as a means of keeping up to date before $C P P$. It was thought to be the best method by 36 per cent of the British physicists, while 37 per cent of United States physicists ranked this method in first place. The physicists indicated, however, that they would welcome a publication that would relieve them of the chore of actually seanning journals, provided that "nothing relevant" was missed. There were various constructive suggestions about the requirements of a current awareness journal, and also comments about available abstract journals. The IEE must be satisfied with the discovery that Physics Abstracts was the most widely used publication in the field, in both Britain and the United States. As the report puts it, "the heavy usage of this existing IEE publication in physics augurs well for the success of a complementary current awareness journal from the same publishers". The next two reports may well show if this is indeed the case. At the moment the IEE appears to be satisfied with the sale of $C P P$ in Britain and in the United States.

\section{Fish Farming}

Fisu farming has been shown to be practicable, but the "rate at which the prospects are converted into reality will depend critically on the research effort we are able to mount". This was the conclusion of Dr H. A. Cole, Director of Fishery Research at Lowestoft, who addressed the Royal Society of Arts last week on the artificial cultivation of sea and shell fish and described the research which must be done bcfore a successful intensive rearing system can be built. There must be "systematic optimization of the environmental factors present in the system followed by scientific breeding to provide animals highly adapted to culture conditions".

The depletion of fish supplies accessible to British fishermen has led to the investigation of alternative sources, and to the realization that artificial cultivation can lead to advantages in processing and marketing, with possibilities for export. Plaice was one of the 
first fish to be investigated, 15 years ago, and much has been learned from rearing young plaice in tanks and ponds from eggs collected at sea. The best conditions of temperature, salinity, light, water exchange and quantity of food have been investigated for plaice. As a result 400,000 were produced in 1965 until they were large enough to take to the bottom of the sea as adult flat-fish. In the future, however, it is likely that sole will be cultivated more widely than plaice, as it is more valuable, the young grow readily and the adults adapt to tank life and can be induced to spawn. This fish favours a warm temperature and is therefore suitable for cultivation in the heated sea water which is put out by power stations. Dr Cole suggested that within ten years sole production at these power station sites will be in full swing, and turbot and brill are likely candidates for the same treatment. Some shellfish also need warm water and can be grown in these warm water wastes.

Oysters of the Ostrea edulis variety were once common in estuaries around Britain, but successive pests and floods have reduced the breeding stock to such an extent that any recovery of the oyster industry will depend on successful artificial rearing. Fifty years of slow but steady progress in artificial breeding at Conway led to commercial scale techniques being used four years ago and a commercial hatchery now being built in South Devon is likely to produce a steady supply of young oysters. New Zealand and Japanese oysters are being investigated, as are American clams. The latter can be planted on the shore at the age of $1-1 \frac{1}{2}$ years, but must be protected from crabs by plastic mesh until they grow to an inch in diameter. After four years they are large enough to be marketable.

The English prawn is another suitable species for artificial cultivation, despite its cannibalistic tendencies, and a habit for producing eggs rather than getting fat. As with all other artificially reared fish, the feeding problem for shrimps has yet to be completely solved. The brine shrimp Artemia is a useful food source for many kinds of fish, but attempts are being made to produce a protein based artificial food. Waste fish flesh and poultry offal may provide the basis of the substance, which must be soft. Attempts are also being made to find a palatable fish which is herbivorous. Grey mullets and the freshwater Tilapia are two possibilities, but as yet there is little demand for these varieties.

\section{Parliament in Britain}

Nationalized Industry Research

THE programmes of the National Coal Board provide for estimated expenditure on research and development in the current financial year of $£ 5$ million. The Gas

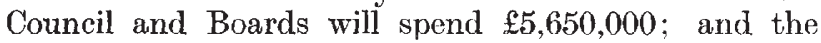
Electricity Council and Boards $£ 10,650,000$. The National Coal Board in 1966 employed 356 qualified staff on research and development, and the Gas Council and Boards 340 ; in the current year the Electricity Council and Boards employed about 900 . The figures were given by Lord Winterbottom concluding a debate for the Government on February 14.

\section{Atomic Energy Authority}

Dr J. BraY, Joint Parliamentary Secretary, Ministry of Technology, stated that the Atomic Energy Authority aimed to achieve cuts of $£ 3.5$ million in 1968-69 in the cost of their civil research and development programme principally by some reduction in capital expenditure and by some run down of manpower. The balance of the cut would be met by limiting extramural research and development contracts. The effect of the cut of $£ 6$ million in 1969-70 was still being studied. by the authority. (Written answer, February 12.)

\section{Scientific Officers}

The Minister of Technology, Mr A. Wedgwood Benn, gave the average age on January 1, 1968, of officers in each grade of the scientific officer class employed in the Ministry's Research and Development Establishments as: chief scientific officer, 52; deputy chief scientific officer, 50; senior principal scientific officer, 47; principal scientific officer, 45; senior scientific officer, 33; and scientific officer, 26. The Minister of Defence for Administration, $\mathrm{Mr}$ G. W. Reynolds, gave the corresponding figures for scientific officers in the Ministry of Defence's establishments: 54; $45 ; 48 ; 46 ; 36 ; 26$. (Written answers, February 12.)

\section{Chemical Defence}

Tue Minister of Defence for Equipment, Mr R. Mason, stated that the work of the Chemical Defence Experimental Establishment was directed towards research on defence against chemical warfare, but some of the work of the establishment had found applications in medical science. Such benefits included the investigation of the mode of action of several toxic compounds leading to the development of measures for treating intoxication; the development of an antidote to poisoning by organophosphorus insecticides (a service providing advice and first-aid treatment had been maintained since 1960); the development of aids to therapy, such as an automatic injection device and a portable resuscitator which is used by fire brigades and other rescue services; the investigation of the structure of the skin and the processes of skin penetration; and the investigation of the nature of the alveolar lining of the lung. Mr Mason later gave the number of qualified engineers and scientists working in defence research and development establishments on December 31, 1967, as 2,838 compared with 2,612 on December 31, 1964. (Written answers, February 13 and 14.)

\section{Protein from Leaves}

Mrs Shirley Williams, Minister of State at the Department of Education and Science, stated that the Rothamsted Experimental Station is carrying out research on the extraction of protein from the leaves of crop plants. Figures for the extractability of leaf (including tree-leuf) protein from many parts of the world were now being published. These were not strictly comparable because of differences in the techniques of grinding and pressing. Measurements of the extractability of protein from local crops were an essential prelude to any attempt to make leaf protein for use as a food in regions of protein deficiency. Unexpected differences had been found in the nutritional value of protein preparations. The effects of variations in the technique of precipitation, filtering and processing or drying the protein would be studied and the National Institute for Research in Dairying and the Rowett Research Institute would co-operate in measuring the nutritional value of some of these products. (Written answer, February 13.) 